\title{
A functional assessment of adolescents who were recipients of bone marrow transplantation: a prospective study
}

\section{Avaliação funcional dos adolescentes que se submetem a transplante de medula óssea}

Maribel P. Doro ${ }^{1}$

Ricardo Pasquini²

Suzane S. Löhr ${ }^{3}$
Theaim of this study was to assess the physical performance (Karnofsky or Lansky's Performance Scale), as well as the social/familial, emotional, functional and cancer treatment by bone marrow transplant (FACT-BMT battery). Subjects were all adolescents (13 to 20 years of age) who underwent a transplant at the Bone Marrow Transplant Unit (Serviço de Transplante de Medula Óssea) of the University Hospital (Hospital de Clínicas) of Universidade Federal do Paraná, (STMO-HC-UFPR) in the calendar year (January to December) of 1999. The initial sample consisted of thirteen patients (seven male, six female), of whom four had a previous diagnosis of a neoplastic condition and nine of a non-neoplastic condition. Allografts were used in all cases. The study instruments and scales were applied twice: firstly, in the month prior to the procedure and secondly, on the hundredth day afterwards. Three patients died before the second assessment was carried out. Therefore, only 10 patients completed the study and were the subject of the full analysis. Results show that although $4 / 10$ of the patients had an improved physical performance as shown by the Karnofsky and Lansky's Performance Scale, 9/10 reported difficulties to resume day-to-day activities and chores (professional, educational and homework), as shown by the FACT-BMT battery. In other domains assessed, results showed variations between the pre and post procedures but without reaching statistical significance. It could be concluded that the therapeutic intervention in itself may affect the quality of life of the subjects. It has to be said, however, that this study was carried out within the frame of continuous medical treatment and this may have acted as a confounder. Further long-term longitudinal studies are, therefore, required to improve our understanding of these issues. Rev. bras. hematol. hemoter. 2003;25(1):5-15.

Key words: Bone marrow transplantation; quality of life.

${ }^{1}$ Psicóloga responsável pelo Serviço de Transplante de Medula Óssea do HCPR.

${ }^{2}$ Serviço de Hematologia e de Transplante de Medula Óssea do HC-PR. Professor titular, Chefe responsável pelo Serviço de Transplante de Medula Ossea.

${ }^{3}$ Professora da graduação e pós-graduação da Universidade Federal do Paraná.

Hospital de Clínicas da Universidade Federal do Paraná - HC-UFPR

Serviço de Transplante de Medula Óssea - STMO

Correspondência para: Maribel Pelaez Doro

Rua: Adolfo Stedile, 201 - Bom Retiro - CEP: 80520-540 - Curitiba-PR

Tel: (41) 254-7107 res - (41) 223-5078 clínica - Cel. 99610450 - Fax: (41) 352-7373

E-mail: maripdoro@uol.com.br 


\section{Introduction}

It can be presumed that Greece served as the birthplace for the first transplants in ancient civilizations, as man already imagined, and demonstrated through myths, the realization of functional and structural alterations of the human body.

Mythology and legends gradually opened the way for real attempts, initially in the vegetable world and soon after in the animal world where all types of grafts were realized. However, the scientific foundation for BMT intervention arose from studies on rats, and later on dogs.

The first attempts to use the infusion of bone marrow for treatment in humans occurred in 1957, while the first successful transplant took place only in 1968. ${ }^{1}$ In Latin America, in the city of Curitiba, Paraná, in Brazil, the University Hospital (Hospital das Clínicas) of the Universidade Federal do Paraná, was the pioneer, in 1979. In this Hospital over 1,200 bone marrow transplants were carried out up to May of 2001 under the guidance of Dr. Ricardo Pasquini.

As a psychologist of this service, in my daily routine I observe many victories, but also many situations of loss, manifested as suffering, complications, sequelae and death. Being as such, I was motivated to want to know more about this treatment, since even in the successful interventions, interference occurred in the biopsycho-social aspects and in the quality of life of those that needed to undergo the transplant.

Bone marrow transplantation

The transplantation of the bone marrow is a therapeutic modality capable of rebuilding the hematopoetic and immune systems in a series of diseases, which can be cured through elevated doses of chemotherapy, associated to or not associated to radiation therapy. ${ }^{2}$ It is a therapy with a high potential for cure but also presents high risks. It is used above all in hematopoetic diseases, when other treatments fail to present results. ${ }^{3}$

Bone marrow transplant is a therapeutic modality of high morbidity and mortality, consequently, even in successful interventions, interference occurs in the physical and psychological performance as well as in social interactions. ${ }^{4,5}$

The transplant of hematopoietic stem cells is a medical modality that is highly stressful, even when it occurs under the best of circumstances. ${ }^{6}$ It is observed that the latest concepts are not restricted to the medical question alone, rather they call attention to multidimensional interference.

If BMT is still a modality of treatment of high mortality and morbidity, how does it affect the adolescent who lives through this experience?

From this question the objective of this study was elaborated.

\section{Objective}

To analyze the physical performance (Karnofsky or Lansky's Performance Scale), as well as the performance at the socio-familial, emotional, functional levels and additional concerns (Functional Assessment of Cancer Therapy - FACT-BMT) of all of the adolescents subject to transplant in the BMT UNIT of the University hospital, in the period from January to December of 1999.

\section{Subjects}

All of the adolescents admitted for treatment in the year 1999 were subjects of the method now being presented. Both sexes, recruited in the outpatient service of the Bone Marrow Transplant Unit of the University hospital, fitting the following inclusion criteria for the study: between 13 and 20 years of age, a candidate for allogeneic bone marrow transplant and having a diagnosis of a neoplastic or non-neoplastic condition, without cognitive alterations that prevent them from responding to the survey on their own, with clinical conditions for undergoing an immediate transplant and with a compatible donor and availability for donation (Table 1 Demographic distribution).

\section{Material}

For the assessment, the following instruments were used: 
Functional Assessment of Cancer Therapy FACT-BMT

This is a multidimensional scale to assess quality of life, filled out by the patient. Besides the additional concerns it includes the following dimensions:
a) physical well-being:
b) functional well-being
c) emotional well-being;
d) social and familial well-being.

Karnofsky Performance Scale

Is a one-dimensional scale, in which the doctor fills out his/her assessment regarding the physical performance of the patient, on a scale from 0 to 100 . Applied to patients sixteen years of age or older.

Lansky Performance Scale

Is a one-dimensional scale, in which the doctor fills out his/her assessment regarding physical performance of the patient, on a scale from 0 to 100. Applied to patients under sixteen years of age.

\section{Method}

The research was divided into two stages: a) pilot study;

b) research, with the inclusion of the application of pre and post-transplant.

Pilot Study

Thirty patients with a diagnosis of hematopoetic diseases undergoing bone marrow transplant treatment at the University Hospital HC-UFPR were consulted regarding their willingness to respond to the survey. The pilot study sought to investigate the level of acceptance, comprehension and susceptibility to the FACT-BMT scale. BMT

First Assessment of the Research - Pre-

The adolescents with a diagnosis of hematopoietic disease were investigated in the month preceding admittance for undergoing transplantation

The patients filled out the Functional Assess-
Table 1

Demographic distribution

\begin{tabular}{lcr}
\hline Data & Number & Percentag \\
\hline Evaluation before & 13 & 100,0 \\
Gender & & \\
Male & 06 & 46,2 \\
Female & 07 & 53,8
\end{tabular}

Age (years)

Mean \pm standard deviation $\quad 15,7 \pm 2,5$

Range

13,0 e 19,4

Diagnosis

AAS

AF

LLA

LMC

LMMC

Karnofsky/Lansky Scale

Mean \pm standard deviation

Range

Karnofsky/Lansky Scale

Mean \pm standard deviation

Range

Mortality

53,8

$02-15,4$

$01-7,7$

$02 \quad 15,4$

13

$81,5 \pm 18,6$

50,0 e 100,0

10

$84,0 \pm 17,8$

50,0 e 100,0
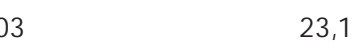

Evaluation after 10

Gender

Male

100,0

Female

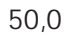

Age (years)

Mean \pm standard deviation

05

50,0

Range

Diagnosis

AAS

AF

LLA

LMC

Karnofsky/Lansky Scale

Mean \pm standard deviation

Range

$15,5 \pm 2,7$

$13,0 \pm 19,4$

$83,0 \pm 25,8$

$40,0 \pm 100,0$

100,0

Statical analysis: Karnofsky/Lansky Scale $=F \quad=0,01$;

$p=0,921$ (ANOVA); $W=0,152 ; p=0,882$ (match analysis)

ment of Cancer Therapy, FACT-BMT. The doctors filled out the Karnofsky and Lansky Performance Scales. 
Second Assessment of the Research - PostBMT

On the hundredth day all of the assessment scales were reapplied.

Statistical Treatment of Data

To verify the objectives found in the study, Analysis of Variance (ANOVA) was used as well as the non-parametric "Wilcoxon" tests by the "Primer of Biostatistics" software), "Chi-Square, with Yates correction and "Fisher Exact", by the "Epi-Info", for related samples.

Results

All of the adolescents submitted to allogeneic transplant of bone marrow in the year 1999, were included in the study.

Pre-Transplant - $(\mathrm{N}=13)$ Thirteen patients, (seven males, six females), ages varied between 13 and 20 (average 15.7). Four patients had a diagnosis of a neoplastic disease and nine of a non-neoplastic disease.

Post-Transplant - $(\mathrm{N}=10)$ Three patients in the first stage died before +100 day, thus there is no record of the second phase. Hence, the analysis of the study was developed in relation to the patients that completed the two stages of the assessment

Karnofsky and Lansky Performance Scales No statistical difference was found between the pre and post-transplant performance. However, the following information was ascertained 3/10 of the patients worsened, 4/ 10 improved and, 3/10 maintained the same score (Figure 1).

Subscale of the functional well-being of the FACT-BMT

A significant difference was found in the work performance aspect in general, $(p=0.0017)$. In the pre-transplant, 9/10 of the patients were capable.

In the post-transplant, 9/10 of these patients were not capable of working including tasks that could be carried out at home (Figure 2 Graph representing patient's involvement with work and studies, pre and post-transplant).

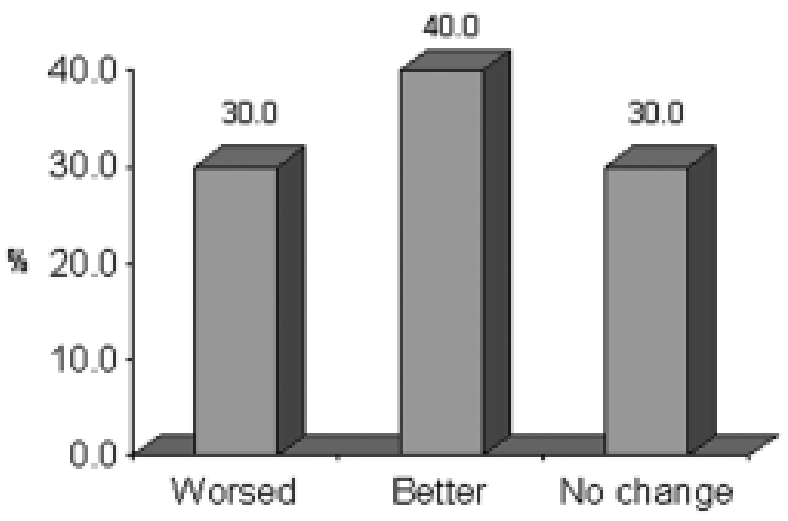

Fig. 1 - Karnofsky/ Lansky pre/pos

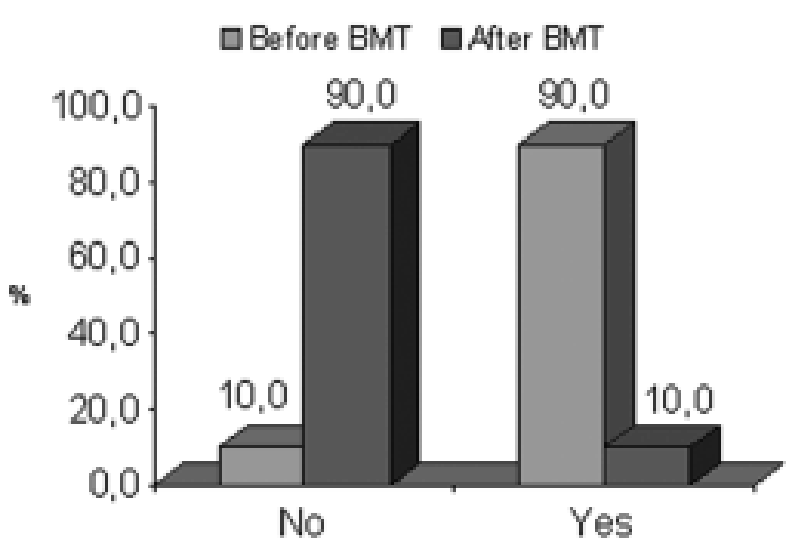

Fig. 2 - Functional well-being BMT

Subscale of physical well-being of the FACT-

Post-BMT more patients experienced nausea and felt a lack of energy. Fewer patients were concerned with the collateral effects of the treatment and fewer patients felt pain (Figure 3).

Subscale of socio-familial well-being of the FACT-BMT

Post-BMT more patients complained of distancing of friends (Figure 4).

Subscale of emotional well-being of the FACT-BMT

Post-BMT more patients had renewed hope, more patients were nervous and fewer patients felt sadness (Figure 5). 


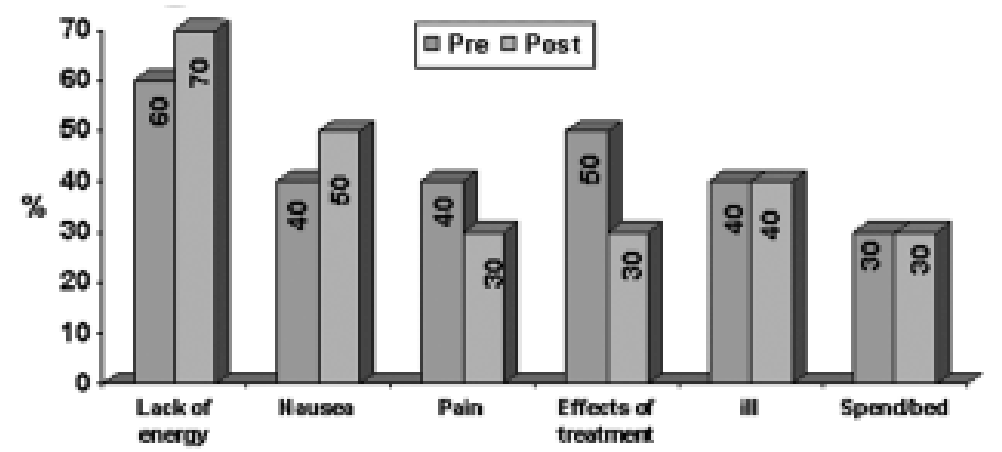

Fig. 3 - Physical well-being. Assessment in pre and post BMT

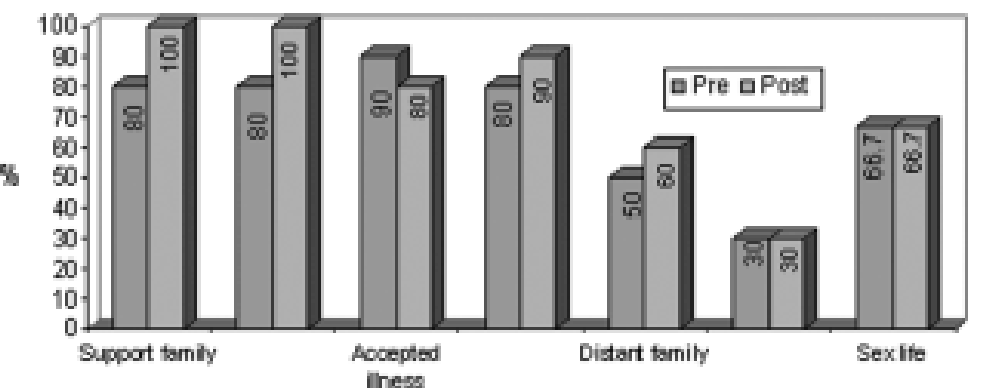

Fig. 4 - Social/Family well-being.

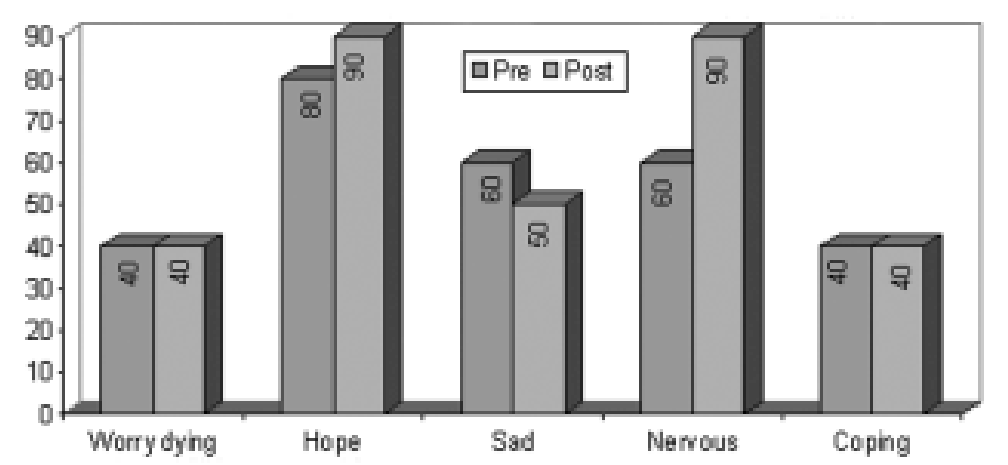

Fig. 5 - Emotional well-being.

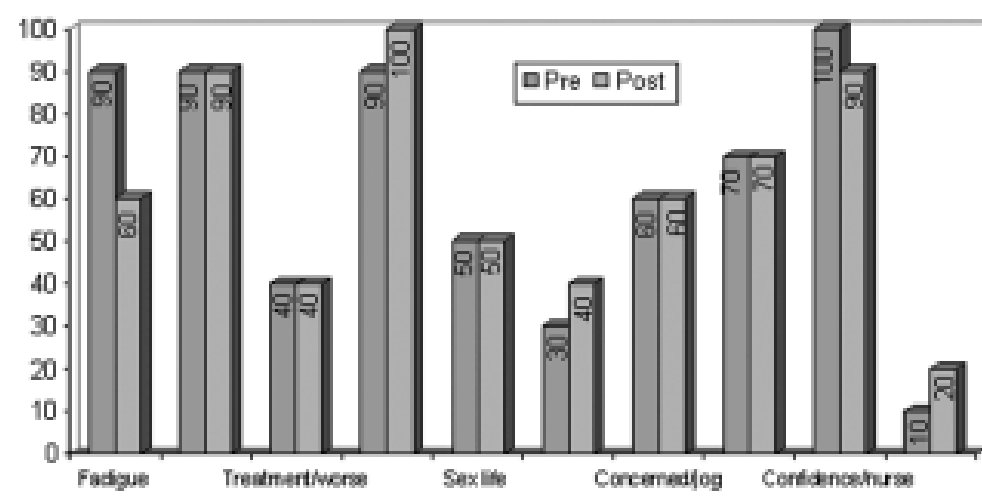

Fig. 6 - Additional concerns
Subscale of additional pre occupations of the FACT-BMT

Post-BMT more patients were concerned with the capacity of having children and regretted having done the BMT. Fewer patients presented fatigue (Figure 6).

\section{Discussion}

Regarding the Demographic Distribution

The Bone Marrow Transplant Service at Hospital de Clínicas in Curitiba BMTS-HC carries out, on an average, one hundred transplants per year. In 1999, thirteen of the transplants were on adolescents, which made up the sample of this study.

Although this sample represents all of the cases of adolescents who underwent bone marrow transplants, the reduced size of the sample makes it impracticable to make generalizations for other populations based on these results. How ever, some of the data collected before and after the transplant show how interventions interfere in the lives of patients.

Discussion of the Results of the Karn ofsky \& Lansky Scales

The results of the Karnofsky and Lansky Scales before and after the transplant did not show a significant difference. How ever, taking into consideration minor oscillations, $3 / 10$ of the patients worsened, 4/10 improved and $3 / 10$ continued with the same score. The latter group, in pre and posttransplant, showed satisfactory performance in routine activities. Just one required occasional assistance, but was able to take care of the majority of necessities, and remained that way. These results suggest that the toxicity of the conditioning did not cause increased restrictions to the patient's physical condition. 
Yates $^{7}$ and Lansky suggest that improvements in the Karnofsky scale, which is associated with the response to treatment, can be used to objectively measure the efficacy of intervention. Thus, despite the fact that not every one improved, we can consider the bone marrow transplant, a form of intervention that can bring about benefits that compensate the general costs.

Discussion of Results of the FACT-BMT Scale

On the physical well-being subscale no statistical difference was detected between pre and post-transplant performance. How ever, findings showed that $5 / 10$ of the patients were concerned about the side effects of treatment before the transplant, compared to only $3 / 10$ after the transplant.

One hypothesis for this change is that with the treatment, a new horizon is opened where the patient increases his/her tolerance to the symptomatic state, since no longer having the primary illness means a change in the focus of the threat; or in other words, when one has the disease, the threat is from the inside out. When one believes that the fatigue, nausea, pain, and indisposition are due to the medication, and that these are temporary and necessary to maintaining the bone marrow with the potential for health, the focus of the etiology of general indisposition is put on the drug being ingested; that is, the threat is from the outside going into the body. Therefore, the diminishing of concern makes one suppose that simultaneously, there is a reduction in the vulnerability and this can be a demonstration that there was a change in perception in relation to the condition of living with the side effects of this treatment.

Upon being asked about the meaning of neoplastic disease, ${ }^{9}$ we found that the patients included descriptions similar to death, terminality, sadness, fear, chemotherapy, mutilations and financial loss. Being in pretransplant means being contaminated with negative feelings, while the transplant can at times make the cure viable.

Moreover, the patient is advised in the pretransplant interview that the critical phase extends to the hundredth day after the transplant. Therefore, being less worried also suggests adjusting one's expectations to reality. This is evidenced in other studies. ${ }^{6,10,11}$

Although there was no significant difference in the findings between pre and post-transplant, on the subscale of social-familial well-being there was an increase in complaints regarding the distancing from friends. This means that the isolation that is required for the transplant can hurt relationships. This same difficulty is reported in some studies by Grant in Forman, ${ }^{12}$ Richardson et $\mathrm{al}^{13}$ and Rourke et al. ${ }^{14}$

The above fact has also been a concern of other centers that carry out bone marrow transplants. Due to the scientific, economic and psychosocial pressure to view patients in the broadest possible light as they carry out their different functions, investments have been proposed for studies and research on a form of intervention called a mini transplant, where the restrictions from the lowering of the immune response and the period of hospitalization is shorter. ${ }^{15}$

According to Wellisch \& Wolcott ${ }^{16}$ and Anders ${ }_{, 17}^{17}$ the positive aspect of social and family support is one of the predictors for greater psychological adjustment. For the group being studied, findings showed that the family and social relationships were favorable, despite the restrictions, threats, isolation and mourning over losses, the bonding capacity did not suffer further setbacks. In Bromberg's studies, ${ }^{18}$ it was found that the diagnosis of a potentially fatal disease can intensely harm the family system, just as the threat of a dying child is also disaggregating. Considering the bone marrow transplant process a time for dealing with such issues, one can expect psychological and relationship problems. However, the data obtained in the study showed that the losses that occurred in this area were not substantial enough to cause an irrecoverable detrimental difference.

Moreover, there was a positive quality to the maintenance of relationships, which means that the results include gains and losses and the latter does not always supersede the former. This information corresponds to the results of the studies by McQuellon et al. ${ }^{19}$

On the emotional well-being subscale no significant difference was found. How ever, after 
the transplant $9 / 10$ of the patients felt nervous, in comparison to $6 / 10$ of the patients before the transplant. Furthermore, there was a concern about death in 4/10 of patients in the two assessments.

On the $+100^{\text {th }}$ day, normally the patient is allowed to go home.

If, on the one hand the patient is allowed to return to living within his/her group of reference, he/she also assumes greater responsibility over the treatment. Facing reality causes the patient to deal with it continuously and for an indeterminate time.

Studies by Neitert et $\mathrm{al}^{20}$ and Andrykowski \& McQuellon in Forman ${ }^{21}$ verify these aspects and justify the changes in this stage by the fact that the transplant is a modality of treatment that interferes with the entire system, on the individual level (mental, physical and spiritual), socio-familial relationships, and in the economic structure (professional/academic).

For Grant in Forman, ${ }^{12}$ in this field of observation they found positive and negative perspectives. These are expressed by the manifestation of fear, anxiety, depression and cognitive alterations. The positive components are: the perspective of receiving a second chance on life, which gives legitimacy to choices and priorities. Another finding is the importance the patient attributes to each day; in other words, how much he/she values being alive. Thus, the transplant is an opportunity for growth and a positive qualification of living.

The results from the functional well-being subscale presented a significant difference in the aspect of work performance in general. During the pre-transplant phase, 9/10 of patients were capable of involving themselves in tasks that could be carried out at home, and in the posttransplant phase, 9/10 of these patients were not capable of working including tasks that could be carried out at home.

McQuellon \& Andrykowski in Atkinson ${ }^{6}$ define complications from the transplant as physical problems and increased psychosocial problems that develop during this process and that hamper the patient's recovery.

They use as an example the prolonged time it takes for engraftment and the recovery of the immune response, as factors that potentially generate anxiety and depression in the patient. They classify the psychosocial complications in three groups:

a) psychiatric disorders, heightened depression resulting in difficulties for adjusting to sleep, eating and experiences of loss in relation to work and social activities;

b) interruption of tasks in normal everyday routines

c) expectations the patient has in relation to the time it will take to get back to his/her normal life. In this study, significant complications were found in the field of daily performance.

We can infer that among the possible variables interfering with the expression of these results is the physical condition of these patients in post-transplant, as they showed a lack of energy; that is, low stamina was observed in 7/ 10 of patients.

This precarious performance reflects the sum of losses in functions associated with the modality of treatment still having a high morbidity.

Furthermore, according to Wellisch and Wolcott, ${ }^{16}$ the family also suffers, at times becoming the patient in the sense of needing assistance and support, since the relationships in this system suffer alterations. It is important to remember that the hundredth day posttransplant is when the patient first returns to activities, this can propitiate co-dependence and overprotection by the family. Thus, there can be a certain difficulty in going home and encouraging independence and a return to responsibilities.

In the group studied, significant attachment and bonding was observed between the patient and family. Consequently, the action and desire can be ambivalent, because at the same time there is a movement towards letting go, there is also a movement of letting go and of protection.

For Wellisch and Wolcott, ${ }^{16}$ the presence of precedents of psychiatric history, a negative quality to socio-familial support and precedents of a history of precarious performance, are predictors of unsatisfactory psychological adjustment. Therefore, we can consider that 
the group being studied has possibilities of significantly recovering their health, since the abovementioned predictor factors are not present.

Furthermore, according to Gratwohl, ${ }^{22}$ the complications related to the transplant are milder when the patient is young.

Another aspect to be considered is that there was a decrease in relation to satisfaction; in pretransplant, in 9/10 of patients, in post-BMT the number decreased to $7 / 10$ of patients. Therefore, the operational reduction also results from low motivation in relation to the attitude of reassuming roles and functions.

on the additional concerns subscale, the study shows that the level of concern remained the same regarding the possibility of getting on with work in general, in 6/10 of the patients observed, even though nine of them led active lives prior to the transplant. In post-transplant only one does not work; nevertheless, concern remains at the initial level, without alterations. If the concern exists whether or not the patient has an activity, this means that being sick or undergoing a transplant is a condition that makes the patient vulnerable, since it generates insecurity regarding temporality and for belonging to an at risk group, whether it is because of the diagnosis received and its implications, or because of the consequences of this modality of treatment.

If the level of concern does not alter in relation to productivity or non-productiveness, we can also assume that the concern is related more to aspects that involve the condition of being alive and as a consequence, the aspects that are involved with living one's life.

The study on psychosocial adjustment by Almeida et $\mathrm{al}^{4}$ agrees with this manifestation, since the quality of life referential was centered on the perception of having rid oneself of the symptoms originating from the primary disease.

Another possible reason that the level of concern does not increase despite a significant loss in the capacity to perform, is that the affliction is rooted in accordance with the focus of perception and not only as a result of real losses. Korzybskyl in Balieiro says that ${ }^{23}$ “... perception has a character of representation, or rather, of codification, that is the transformation of the perceived object into objects or elements of another order, another code, in this case of an abstract mental character. These mental objects are evidently not the thing perceived. Since subjective thinking is the process of attributing value, since perception does not create the object, it attributes it, the same happens with valuation."

Thus, the patient will more or less use his/ her real condition. The perceptive valuing will be expressed in the judgment and interpretation. In short, the subjective value of his/her capacities and limitations is included in the operational capacity of the patient. Thus, for example, the patient that walks with a cane can say: "I don't walk without support" or: "I walk with support". One patient is talking about the lack of something and the other about what he is able to do despite the lack of something.

There is a set of factors that induce the individual to give greater importance or less importance to what he/she experiences. These rules of codification are constituted by the genetic potential, personality and the sociocultural and historic reference.

According to Werneck's thoughts (p. 19 and $25),{ }^{24}$ "... value is known by experiencing sensibility and not only towards the idea, in a process of rationalization .... . The effort of reason is made in the sense of knowing the thing independently of its value. To what degree this is possible is difficult to indicate with exactness; this is the objective, the intent, but what it seems to be never is achieved completely since what attracts to the knowledge of the object is, before anything else, its value."

of the nine patients that work, six were concerned with the continuity of activities. If we analyze the patients' socioeconomic class (lower middleclass), the need for active participation that these adolescents have becomes clear. If we consider the subjective thinking of each patient, this assessment can follow other valuation.

There was no significant decrease in fatigue - 9/10 of patients in pre-transplant, compared to $6 / 10$ in post-transplant - which corresponds to the assertions of Neitzert, et al, ${ }^{20}$ 
that this is a common complaint that can persist for various years among patients that undergo a transplant. It is possible to think of a potentiality for improvement, since Vogelzang et al ${ }^{25}$ showed that $60 \%$ to $96 \%$ of patients that undergo chemotherapy suffer from fatigue during treatment. This information corresponds to the results found in the pre-transplant phase of our group. With the transplant, after chemotherapy or in the absence of it, there is a decrease in the number of complaints.

Furthermore, Neitzert, et al ${ }^{20}$ says that besides the physiological functioning, the psychological and situational factors contribute to the manifestation of fatigue. When the interventions include psychological care, they put the patient in a context and the doctor/ patient communication improves, showing a decrease in the effects of fatigue.

Spiege ${ }^{26}$ demonstrated that taking care with aspects that can alter the patient's mood and dilute the depression is a therapeutic attitude that contributes to better adjustment, a decrease in symptoms and can have greater or less interference in the course of the disease.

The patient's relationship with the pre and post-transplant reality is mediated by perception, indicating the aspect of uniqueness, not collectivity. According to Balieiro it is easier for the individual to perceive a given characteristic for which there was already an internal latent representation in his/her perceptive schemes. Thus, the reaction can be the result of facts and the personal capacity to perceive, understand and learn.

In this study, the patient was responsible for filling out the survey before and after the transplant. The perceptive variables remained constant. The value lies in how the patient perceives the self before the therapist, the specific disease and its interference in the quality of life. What is interesting to observe is that the perceptive quality of the patient can be transformed and this is the area of action that is of fundamental importance to the psychologist. It contributes to the patient's drawing upon what he/she has and with it, building the means to supplant the real losses and recreate alternatives that make life worth living.

\section{Conclusion}

The adolescents on the hundredth day PostBMT showed a significant loss in the functional condition, in professional, academic and domestic activities. This result could be the result of a lack of autonomy, interfering negatively in the Quality of Life.

The assessment of operational capacity regarding autonomy - is fundamental when one desires to compare treatments or make decisions regarding therapies and palliative care. Fatigue can compromise the quality of life and is a frequent complaint among transplanted patients. Therefore, a more detailed look at this issue becomes important, so that there is greater precision in the findings.

This study requires continuity to clarify the biopsychosocial conditions of the patients undergoing this modality of treatment, analyzing the process beyond the hundredth day Post-BMT.

The losses resulting from this intervention can be alleviated or made up for by socio-familia support, by the team's biopsychosocial intervention and by the appropriateness of the patient's expectations with regard to the results and the acceptance of his/her situation.

In Bone Marrow Transplant there are no stand-ards of predictability, since there is reduced immunity, there is a high intake of medicine and significant toxicity and the subjectivity of each individual patient. These integrated elements leave him/her at the mercy of predictable unpredictability.

\section{Acknowledgment}

The authors wish to thank Maria Eliza Massako Kaahara and Katiucha Reixdorfer for their help in the application of the test.

\section{Resumo}

O estudo teve por objetivo an alisar o desempen ho físico (Escala de Desempenho de Karnofsky ou de Lansky), assim como o desempenho sociofamiliar emocional, funcional, relacionamen to médico/paciente e preocupações adicionais (Escala de Avaliação Funcional para Terapia de Câncer - Transplante de 
Medula Óssea - FACT-BMT) de todos os adolescentes (13 a 20 anos) submetidos a transplante no Serviço de Transplante de Medula Óssea do Hospital de Clínicas da Universidade Federal do Paraná, (STMOHC-UFPR) no período de janeiro a dezembro de 1999. Inicialmente eram 13 pacientes (sete homens, seis mulheres); quatro com diagnóstico prévio de patologia neoplásica e nove não-neoplásica, levando em conta que todos foram submetidos a transplante alogênico. Os instrumentos de coleta de dados foram aplicados em dois momentos: durante o mês que antecedeu o transplante e no centésimo dia após o mesmo. Três pacientes do grupo inicial foram a óbito antes da segunda coleta. Assim, apenas dez completaram as duas etapas da avaliação e constituíram a amostra de análise $(n=10)$. A avaliação dos resultados demonstrou que $4 / 10$ dos pacientes a presentaram meIhoras em relação ao desempenho físico (resultados da Escala de Desempenho de Karn ofsky e de Lansky), no entanto 9/10 relataram dificuldades para reassumir as atividades regulares (profissional, educacional e domésticas), resultados da FACT-BMT. Os demais tópicos avaliados demonstraram oscilações do pré para o pós-TMO, porém de baixa amplitude e sem diferença estatística significativa. Pode-se concluir que a interven ção em si compromete parcialmente a qualidade de vida dos pacien tes. No entanto, é preciso considerar o fato da avaliação ter sido realizada no período em que os pacientes ainda estavam sob tratamento médico contínuo, uma vez que esta contextualização é uma variável interferente. Assim, estudos futuros devem ocorrer para avaliar a evolução longitudinal desse processo. Rev. bras. hematol. hemoter. 2003;25(1):5-15.

Pala vras-chave: Transplante de medula óssea; qualidade de vida.

Referências Bibliográficas

1. Küss R, Bourget P. An illustrated history of organ transplantation. Publications Laboratory Sandoz. Los Angeles 1992, $175 \mathrm{p}$.

2. O rtega ETT, Neves MI. Transplante de medula óssea. In: Einloft L. Enfermagem em UTI Pediátrica. Editora Médica e Científica Ltda. Rio de Janeiro. 655p.

3. Ahles TA, Tope DM, Funrstenberg C, Hann D, Mills L. Psychologic and neuropsychologic impact of autologous bone marrow transplantation. Journal of Clinical Oncology 1996;14(5):1457-1462.

4. Almeida AC, Loureiro S, Voltarelli JC. O ajustamento psicossocial e a qualidade de vida de pacientes submetidos ao transplante de medula óssea. Medicina, Ribeirão Preto. 1998;31:296-304. Abril/junho.
5. Wingard JR. Quality of life following bone marrow transplantation. Current Opinion in Oncology 1998. 10:108-111

6. McQuellon RP, Andrykowski MA. Psychosocial complications of hematopoietic stem cell transplantation. In: Atkinson $\mathrm{K}$. Clinical bone marrow and blood stem cell transplantation. Boston, Massachusetts, USA, 2000, $2^{\mathrm{a}}$ ed. 1500p.

7. Yates JW. (1980) Evalution of patients with advanced cancer using the Karnofsky Performance Status. American CA Society 1980;45 (8):2220-2224.

8. Lansky SB, List MA, Lansky LL, Sterr CR, Miller DR. The measurement of performance in childhood cancer patients. Reprinted from Cancer 1986, Volume I. Copyright by J. B. Lippincott Company.

9. Leigh SA, Clark EJ. Psychosocial aspects of cancer survivorship. In: Berger A, Portenoy RK, Weissman DE. Principles and practice of supportive oncology. Lippincott-Raven Publishers, Philadel phia 1998, 953p.

10. Devos M, Fontaine. 0 "Retourner á la normale"aprés une greffe de moelleosseuse. Les attentes du patient et leur retentissement sur la qualité de vie". Abstrat. Unité de thérapies comportementales 1998.

11. Kopp M, Schweigkofler H, Holzner B, Nachbaur D Niederwieser D, Fleischhacker WW, SpernerUnterweger $\mathrm{B}$. Time after bone marrow transplantation as an important variable for quality of life: results of a cross-sectional investigation using two different instruments for quality of life assessment. Ann Hematol 1998;77(1-2):27-32.

12. Grant M. Assessment of quality of life following hematopoietic cell transplantation. In: Forman SJ, Donnal T, Blume KG. Hematopoietic cell transplantation. Second Edition. USA. 1999, $1.260 \mathrm{p}$.

13. Richardson RC, Nelson MB, Meeske K. Young adult survivors of childhood cancer attending to emerging medical and psychosocial needs. Journal of Pediatric Oncology Nursing 1999;16(3):136-144.

14. Rourke MT, Stuber ML, Hobbie WL, Kazak AE. Posttraumatic stress disorder: understanding the psychosocial impact of surviving childhood cancer into young adulthood. Journal of Pediatric Oncology Nursing 1999;16(3):126-135.

15. Mehta J, Powles R. The future of blood and bone marrow transplantation. In: Atkinson K. Clinical bone marrow and blood stem cell transplantation. Boston Massachusetts, USA. $2^{a}$ ed. 2000, 1.500 p.

16. Wellisch DK, WolcottDL. In: Donnall T, Forman SJ, Blume KG. Bone marrow transplantation. Blackwell Scientific Publications. Cambridge, Massachusetts. 1994, $1^{\text {ạ }}$ ed. 942p.

17. Anders JC. A família na assistência à criança e o adolescente submetido ao transplante de medula óssea: a fase pós-TMO. Dissertação apresentada ao Programa de PósGraduação. Area de Enfermagem em Saúde Pública da Escola de Enfermagem de Ribeirão Preto da Universidade de SP, 1999 
18. Bromberg MHPF, Kovács MJ, Carvalho MMMJ, CarvaIho VA. Vida e morte: laços da existência. Casa do Psicólogo. São Paulo, 1996, $121 \mathrm{p}$

19. McQ uellon RP, Russel GB, Rambo TD, Craven BL, Radford J. Perry JI, Cruz J, Hurd DD. Quality of life and psychological distress of bone marrow transplant recipients: the "Time Trajectory" to Recovery Over the First Year. Bone Marrow Transplantation 1998;21(5): 477-486.

20. Neitzert CS, Ritvo P, Dancey J, Weiser K, Murray $C$ Avery J. The psychosocial impact of bone marrow transplantation: a review of the literature. Bone Marrow Transplantation 1998;22:409-422.

21. Andrykowski MA, McQuellon RP. Psychological issues in hematopoietic cell transplantation. In: Forman SJ Donnall T, Blume KG. Hematopoietic cell transplantation. Second Edition. USA. 1999, 1.260 p.

22. Gratwohl A. Bone marrow transplantation today. Support care cancer 1994;2:27-34 Springer-Verlag.
23. Korzybskyl apud Balieiro AP Junior. Mecanismos do poder corruptor. Psicologia Ciência e Profissão 1999, 19(3):52-59.

24. Werneck V. Educação e sensibilidade. Um estudo sobre a teoria dos valores. Forense Universitária. Rio de Janeiro. 1996. $134 \mathrm{p}$

25. Vogelzang NJ, Breitbart W, Cella D, Curt GA, Groopman JE, Horning SJ, Itri LM, Johnson DH, Scherr SL, Portenoy RK. Patient, caregiver and oncologist perceptions of cancer-related fatigue: results of a tripart assessment cancer-related fatigue: results of a tripart assessment
survey. Seminars in Hematology 1997;34(3)(suppl2): 4-12.

26. Spiegel D. (1996) Cancer and depression. British Journal of Psychiatry 1996,168(suppl30):109-116.

Recebido: $27 / 12 / 2002$

Aceito: $27 / 01 / 2003$ 